\title{
Interface between management control systems and strategy and performance measures in a family business ${ }^{\star, * *}$
}

\author{
leda Margarete Oro ${ }^{1}$ \\ (D) https://orcid.org/0000-0002-2239-531X \\ Email: ieda.oro@unoesc.edu.br \\ Carlos Eduardo Facin Lavarda ${ }^{2}$ \\ (D) https://orcid.org/0000-0003-1498-7881 \\ Email: eduardo.lavarda@ufsc.br \\ ${ }^{1}$ Universidade do Oeste de Santa Catarina, Departamento de Administração, Chapecó, SC, Brazil \\ ${ }^{2}$ Universidade Federal de Santa Catarina, Departamento de Ciências Contábeis, Florianópolis, SC, Brazil
}

Received on 08.27.2017 - Desk acceptance on 09.19.2017 - $5^{\text {th }}$ version approved on 04.09.2018 - Ahead of print on 09.03.2018

Associate Editors: Rubens Famá and Claudio Wanderley

\begin{abstract}
This study aimed to analyze how the interface occurs between the management control systems (MCSs) and the strategy and performance measures in a family business, from the perspective of Contingency Theory. The relevance of the theme lies in understanding how the use of the managerial levers from the Levers of Control (LOC) model (Simons, 1995) is perceived by the senior management of a family business in the interface with the strategy and performance measures. In terms of its impact in the area, this article broadens the field of research that uses the LOC model together with strategy and performance measures in family businesses. The research methodology used combined methods, operationalized by the case study procedure. The content analysis was performed using coded categories based on the literature and selected passages from the interviews, observation, and documents, by means of qualitative analysis software. As a result, it was observed that the family management designed by the controlling owner, with an entrepreneurial vision, working together (father and sons), and the organizational values of the family unit (belief systems), showed particularities of the family-business duality that contributed to the implementation of the strategy and the use of performance measures. It is also inferred that the two systems (diagnostic controls and interactive controls) are complementary in the organization and that the "customized control" produced by the integrated management system is an adjustment of the MCS to the contingencies in order to enable the interface with the strategy and performance measures. The study revealed that the family values present in the management take form in the belief systems that shape the use of the MCSs and in the strategic behavior of the organization, which is an element that is barely discussed in Simons (1995) and opens up room for new research.
\end{abstract}

Keywords: Management Control Systems, strategies, performance measures, family business.

Correspondence address

leda Margarete Oro

Universidade do Oeste de Santa Catarina, Departamento de Administração

Rua Nereu Ramos, 3777 D - CEP 89813-000

Seminário - Chapecó - SC - Brazil

*Article presented at the XI ANPCONT Congress, Belo Horizonte, MG, Brazil, June 2017.

**The author leda Margarete Oro thanks the support received from Fundo de Apoio à Manutenção e ao Desenvolvimento da Educação Superior (FUMDES) from Santa Catarina. The author Carlos Eduardo Facin Lavarda thanks the support received from Conselho Nacional de Desenvolvimento Científico e Tecnológico (CNPq). 


\section{INTRODUCTION}

Family businesses are generally seen as risk averse, conservative, and stagnated (Kammerland \& Essen, 2017), but recognized as drivers of technological innovation (Zahra, 2005). The strategy of innovating can emerge in response to external demands, such as a change in the economy, competitor behavior, the workforce, and government regulations (Moores \& Mula, 2000).

A recent study (Duran, Kammerlander, Essen \& Zellweger, 2016) found that investment in innovation in family businesses is no greater than that of non-family businesses; but they were shown to be more efficient in the processes. However, Patel and Chrisman (2014) revealed that investment in research and development $(\mathrm{R} \& \mathrm{D})$ in family businesses was carried out differently from in non-family businesses, whose strategies observed resources to prevent socioemotional characteristics and financial wealth.

The strategy of acting in a differentiated way and via innovation imposes challenges on management that normally, in family companies, derives from changes in succession and from company growth. For Moores and Mula (2000), changes can influence the use of controls, and Hsu and Chang (2011) suggest the existence of a positive relationship between the family's influence and the use of strategic controls. Moreover, transition periods in family businesses can also have implications for the use of management control systems (MCSs), because one of the ways for a company to survive in complex and uncertain environments is to understand the role of such systems in creating a competitive advantage (Simons, 1995; Widener, 2007). However, there are divergences regarding the family's influence in the innovation process and there is not yet much empirical evidence about the way MCSs (in terms of levers of control) help or not in this process.

In the MCS model proposed by Simons (1995), called levers of control (LOC), the beliefs reinforce the organizational values. The boundaries play a more constraining role, aiming to minimize risks. The diagnostic use represents the management controls traditionally used, while the interactive use focuses on the strategic uncertainties by means of the adoption of emerging strategies. Moreover, the interactive use includes managerial mechanisms that are consistent with the organization's objectives and strategies (Merchant \& Van Der Stede, 2007). For Bruining, Bonnet, and Wright (2004), the structure of the LOC model presents important variables from the literature to achieve the strategy.

In the search to understand how the MCSs contribute to improving performance by aligning themselves with the strategy, Contingency Theory (Chenhall, 2003), among other theories, is used. Research that uses this theory and focuses on strategy and MCS has contributed to understanding the particularities of a company's management system that differentiate it from others (Cadez \& Guilding, 2008).

The study considers that a family business is one that has family members in the ownership or in the management/company (Gersick, Davis, Hampton \& Lansberg, 1997). The context of the study is a large-sized business from the Brazilian footwear and textiles segment, a sector that is under constant strategic renovation (Bruno, 2016). Considering the above, the study explores how the innovation process occurs in a family business and how the MCSs carry out the interface with this process in order to make viable the successful implementation of the differentiation and innovation strategy. Thus, the aim of the study is to analyze how the interface occurs between the use of MCSs and strategy and performance measures in a family business, from the perspective of Contingency Theory.

In Brazil, studies that have analyzed MCSs indicate an affinity between the attributes of managerial control and the different contexts of organizations (Alves, 2010; Beuren \& Oro, 2014; Beuren, Santana \& Theis, 2014; Canan, Martins \& Oda, 2016; Cruz, Frezatti \& Bido, 2015; Diehl, 2006; Isidoro, 2012; Junqueira, 2010; Lavarda \& Pereira, 2013; Nisiyama, Oyadomari, Yen-Tsang \& Aguiar, 2016; Oyadomari, 2008; Oyadomari, Cardoso, Silva \& Perez, 2010; Oyadomari, Frezatti, Mendonça, Cardoso \& Bido, 2011; Oyadomari, Pedrique, Bido \& Rezende, 2014; Pletsch \& Lavarda, 2016).

Using the results of this study, the aim is to contribute to the literature on family businesses by examining concepts of the LOC framework (Simons, 1995) in the perception of family-member managers from the two different generations (father and sons). Another point is to understand how the MCSs, especially the use of the belief systems and interactive systems, are revealed in a largesized family business in the process of transitioning and where there are two generations in command. Studying a family business that adopts an innovation strategy can indicate empirical evidence about the continuity and permanence of company control.

The article begins with this introduction. Next, the literature review and the research assumptions are presented. Then, the methodological procedures are addressed, followed by the description and analysis of the results, and finally, the closing remarks and recommendations of the study. 


\section{LITERATURE REVIEW AND RESEARCH ASSUMPTIONS}

\subsection{Interface between MSC and Strategy}

The literature review considers the interface between MCSs and strategy and performance measures in family businesses, by pondering that the contingency factors of a MCS are designed so that it is not a universal system, but rather one that should be adapted to a specific context (Otley, 1980). It is understood that MCSs are adjusted in family businesses in accordance with the contingencies derived from the typology (conservative or entrepreneurial) (Miller \& Friesen, 1982).

A differentiation strategy takes into account an organization in relation to its competitors, to the image of the brands, and to the relationship with the target public, which are attributes that are widely discussed by the literature (Miller \& Friesen, 1982; Porter, 1980). Regarding the product innovation strategy, this suggests the competitive context of innovation, creation, and development, processes, and finally, technology used for innovation (Bisbe \& Otley, 2004; Davila, Foster \& Li, 2009; Miller \& Friesen, 1982; Organization for Economic Co-Operation and Development, 2005).

Various functions have been attributed to MCSs, indicating that their use can guide organizations toward achieving superior decision-making, such as in product innovation (Bisbe \& Malagueño, 2009) or in the relationship with fulfilling the strategic objectives (Marginson, 2002). However, the results of the study by Bisbe and Otley (2004) do not support the principle that the interactive use of MCSs favors innovation.

Innovation (as a process or as a result) has been a recurrent theme in the studies on family and non-family businesses (Craig \& Dibrel, 2006; Craig, Dibrell \& Garret, 2014; Padilla-Meléndez, Dieguez-Soto \& GarridoMoreno, 2015). Patel and Chrisman (2014) found that family businesses are able to reconcile economic and non-economic objectives, investing in innovation in a more consistent way and with reduced risk, with the aim of increasing sales.

The LOC framework (Simons, 1995) for MCSs is structured around beliefs systems, boundary systems, diagnostic control, and interactive control. Beliefs systems represent a set of concepts around which the organization defines its fundamental values and principles. For Widener (2007), the beliefs system communicates fundamental values, with the aim of inspiring and motivating the collaborators to research, explore, create, and develop appropriates actions. In a family business, the beliefs system can be influenced by the institutional values and be identified via the family surname, the founder figure, or the organizational culture (Sharma, Chrisman \& Chua, 1997; Lourenço \& Ferreira, 2012).

Carlock and Ward (2001) recommend that the family members discuss with the management team the values, aims, strong and weak points, threats, and potential opportunities. This collaborative process establishes a shared vision of the strategic objectives. When families establish a business, predominant beliefs and norms tend to be passed on to the business. Thus, one characteristic that distinguishes family businesses from non-family businesses is that they inherit or convey beliefs and norms as part of their social structure (Gersick et al., 1997).

Boundary systems impose the constraints on behavior, encouraging compliance with rules, they play a more constraining role, aiming to minimize risks, and they seek to establish terms of conduct for the employees' actions in the business opportunities (Simons, 1995). Operationally, this control system is implemented via a code of conduct, ethical code, and strategic planning systems formalized and instituted via internal mechanisms that enable access for all interested parties.

In a family business, changes occur gradually, with the growth of the organization and the need for adjustments to the management processes, as the transition from the owner-founder to the other generations occurs (Cruz \& Nordqvist, 2012). These managerial changes favor and stimulate the competitive strategy (Cruz \& Nordqvist, 2012), as well as the need to adapt the management controls to the organizational dynamic. The involvement of the first and second generations in the management of the business enables the transmission of knowledge and experience, since this concerns business knowledge, norms, principles, and values, which are precepts of the family unit (Gersick et al. 1997). These arguments provide the basis for the following assumption:

\footnotetext{
Assumption 1: the belief systems and boundary systems enable the implementation of the differentiation and innovation strategy in the family business.
}

Diagnostic control systems, according to Simons (1995), are formal information systems that managers use to monitor organizational results and correct deviations (Chenhall, 2003) from preestablished performance parameters that can also be used as a strategic control. 
Interactive control systems consist of "emerging threats and opportunities that can invalidate the assumptions upon which the current strategy is based" (Simons, 1995, p. 215). This system seeks to stimulate organizational learning to explore strategies emerging in times of change or crisis, especially when organizations seek to redefine their guidelines.

Simons (1994) and Marginson (2002) discovered a positive association in the relationship between diagnostic controls and interactive controls and business strategy. Widener (2007) found a positive and consistent association between diagnostic controls (similar to formal controls) and innovation in businesses that are highly inclined towards learning. Acquaah (2013) found an influence of the use of MCSs on business strategy in family businesses.

Bedford, Malmi, and Sandelin (2016) analyzed the interdependences between management control practices and defensive and prospective businesses. The results showed that the efficiency of diagnostic controls and interactive controls is determined not only by the adjustment to the strategic context, but also by how well they fit each other. Nisiyama et al. (2016) investigated the use of MCSs with operational management techniques in the autoparts industry. The results indicated that the diagnostic use of MCSs was positively associated with cost reduction objectives. Moreover, the interactive use of MCSs was positively associated with the objectives of launching new products. Based on the premises of the literature, the following theoretical assumption is made:

Assumption 2: the interface between the MCSs and the business strategy is facilitated by the use of interactive management controls (adaptation to the environment) and diagnostic management controls (implementation of the strategy) in the family business.

\subsection{Interface between MCS and Performance Measures}

Contingency Theory can be used to explain and predict the conditions under which MCS use is associated with performance measures (Chenhall, 2006). Performance measures were used as variables to predict and explain the dependence in relation to contextual variables (Acquaah, 2013; Anderson \& Reeb, 2003; Oyadomari et al., 2011).

When returns do not fulfill managers' expectations, it may also be the result of a lack of operational or strategic controls. The main problems that can occur with the lack of operational controls include loss or impairment of assets, loss of revenues, excessive costs, imprecise reports and records - which can lead to unproductive measures - and legal sanctions or interruptions to business. At a strategic level, the decisions are generally long term and associated with senior management (Merchant \& Van der Stede, 2007); in this case, MCSs help with financial and non-financial measures. For Henri (2006), managers use performance measures in both controls, interactive and diagnostic, and aim to improve organizational capacities.

Family businesses, as well as other organizations, require financial and non-financial information to establish a viable revenues and costs structure. Various studies on family businesses have used economic-financial measures to evaluate performance (Acquaah 2013; Miller, Le Breton-Miller, Lester \& Canella, 2007; Zahra, 2005). Another study reports Balanced Scorecard (BSC) indicators as a source of information in family businesses (Craig \& Moores, 2010).

In this context, it follows that understanding the process of use and interface of MCSs in the management of a family business, from the perspective of Contingency Theory, contributes to the understanding of how and why organizations promote a competitive strategy and, consequently, seek better performance, guaranteeing sustainability and survival for the following generations. The arguments provide the basis for the following assumption:

Assumption 3: the MCSs (diagnostic and interactive) enable the decision-making processes with the use of financial and non-financial performance measures in the family business.

\section{RESEARCH METHOD}

The study is characterized as a case study. The purpose of a case study is to get to know an organization and understand, in depth, the hows and whys of the occurrence of certain phenomena, showing their identity and own characteristics in the aspects of interest to the researcher (Yin, 2010). The case study option enabled the interface to be identified between the MCSs, the strategy, and the performance measures in the family business.

The choice of the case in this study came about based on its relevance. For the case selection, empirical evidence was initially sought of information related to family businesses that featured innovation as a company challenge and were located in the South Region of Brazil. The chosen case represents a family-owned group of large- 
sized companies, whose industrialized products require investment in technology and innovation.

The research construct aims to identify the presence of observable elements and indicate how these manifestations can be captured by the constitutive definitions (Bisbe, Batista-Foguet \& Chenhall, 2006) for evaluating, understanding, and positioning with regards to informational aspects. Table 1 presents the categories, the subcategories, and the authors that form part of the construct.

Table 1

Research construct

\begin{tabular}{|c|c|c|c|}
\hline Category & Subcategory & Constitutive factors & Authors \\
\hline Corporate strategy & $\begin{array}{l}\text { Conservative or } \\
\text { entrepreneurial }\end{array}$ & $\begin{array}{l}\text { 1. Environmental uncertainty } \\
\text { 2. Information systems } \\
\text { 3. Structure } \\
\text { 4. Differentiation } \\
\text { 5. Product innovation }\end{array}$ & $\begin{array}{l}\text { Acquaah (2013), } \\
\text { Miller and Friesen (1982), } \\
\text { Porter (1980). }\end{array}$ \\
\hline $\begin{array}{l}\text { Management } \\
\text { control systems }\end{array}$ & $\begin{array}{l}\text { Belief systems } \\
\text { Boundary systems } \\
\text { Diagnostic controls } \\
\text { Interactive controls }\end{array}$ & $\begin{array}{l}\text { 1. Organizational vision, mission, and values } \\
\text { 2. Rules and boundaries } \\
\text { 3. Formal and traditional reports and controls } \\
\text { 4. Learning initiatives, discussion, and information } \\
\text { monitoring }\end{array}$ & $\begin{array}{l}\text { Acquaah (2013), } \\
\text { Carlock and Ward (2001), } \\
\text { Oyadomari (2008), } \\
\text { Simons (1995), } \\
\text { Widener (2007). }\end{array}$ \\
\hline $\begin{array}{l}\text { Family involvement } \\
\text { in management }\end{array}$ & $\begin{array}{l}\text { Ownership, family, } \\
\text { management/company }\end{array}$ & $\begin{array}{l}\text { 1. Control of the property } \\
\text { 2. Family members } \\
\text { 3. Evolutionary stage }\end{array}$ & Gersick et al. (1997) \\
\hline $\begin{array}{l}\text { Performance } \\
\text { measures }\end{array}$ & $\begin{array}{l}\text { Economic-financial and } \\
\text { non-financial indicators }\end{array}$ & $\begin{array}{l}\text { 1. ROA, ROE, EBITDA, growth of sales } \\
\text { 2. Clients, internal learning processes, and } \\
\text { innovation }\end{array}$ & $\begin{array}{l}\text { Craig and Dibrell (2006), } \\
\text { Frezatti, Bido, Cruz, and Machado (2014), } \\
\text { Kaplan and Norton (1997). }\end{array}$ \\
\hline
\end{tabular}

EBITDA = earnings before interest, taxes, depreciation, and amortization; $R O A=$ return on assets; $R O E=$ return on equity.

Source: Prepared by the authors.

It is understood that the authors and the categories in Table 1 reflect the theoretical position followed by the study. However, as a case study is concerned, the data collection and analysis tools were fundamental for understanding the meaning and the experience of the managers in the chosen categories.

The information needed for the research was laid out in a case study protocol. The protocol contained the research questions, the objectives, and the definition of the methodological procedures used, the researchers' cover letter, and the Free and Informed Consent Form (FICF). The FICF clarified the study objective, the procedures, and the participation of the respondents in the research, as well as assuring that the respondents' identity would not be revealed and their confidentiality would be preserved.

The procedures used to collect the data in this study were interviews, documents, and observation. Regarding the typology of the interviews, a previously established semi-structured script was followed, but with the freedom to adapt the questions to the investigative context, with support from the literature and assumptions that emerged as the information was reported. For example, questions that included the emergence, evolution, and milestones of the company were regrouped, and the interviewees used institutional material at the same time as they addressed the subject, and they showed images and photos, reporting all the points of the interview.

As a study involving a family business was concerned, the interviews were carried out with the managers that formed the family unit, which in this case represent the key informants (Yin, 2010). The key informants correspond to five people, three of whom are from the family unit. The managing family is composed of the father [chief executive officer (CEO), member and chairman of the board of directors, founder-owner with $93 \%$ of the equity] and two sons in strategic management positions, and there were no other members of the family unit in the management. Thus, the family-member managers suggested two employees that do not form part of the family but who have worked in the companies for 20 years to participate in the interviews.

The interviews were carried out at four different times, in June and July of 2014. The other information, such as documents and organizational records referring to the period from 2011 to 2013, were conceded during the visits, by email, and over Skype. The locations were the administrative units located in the south of Brazil. Table 2 presents the list of research subjects. 
Table 2

Research subjects

\begin{tabular}{ccc}
\hline Managers & Position & Sport Group \\
\hline 1 & Strategic information manager & $55 \mathrm{~min}$ \\
\hline 2 & Product development manager (footwear) & $1 \mathrm{~h} 17 \mathrm{~min}$ \\
\hline 3 & Product development manager (apparel) & $1 \mathrm{~h} 45 \mathrm{~min}$ \\
\hline 4 & Board member, director, and CEO & $1 \mathrm{~h} 30 \mathrm{~min}$ \\
\hline 5 & Accounts director & $1 \mathrm{~h} 45 \mathrm{~min}$ \\
\hline
\end{tabular}

$\mathrm{CEO}=$ chief executive officer.

Source: Prepared by the authors.

The managers interviewed, as shown in Table 2, combine the attributions and qualifications needed to contribute to the scope of this study. In order to guarantee the reliability of the information, the interviews were recorded with the consent of the interviewees. Then, the content was transcribed and the text submitted to the managers for their approval. The transcription resulted in 59 pages of records.

Besides the interviews, the following documents were used: family group history (anonymously called Sport Group), annual reports of complete financial statements referring to the years from 2011 to 2013 and published in the official state gazette with the opinion of independents auditors, code of conduct, reports published on websites, company information extracted from the Sport Group website, and emails exchanged with the research subjects. Besides these documents, financial and non-financial performance measures used in the decision-making process extracted from the integrated management system were used. This information was collected up to December of 2014.

The non-systematic observations occurred in the field visits, at the same time as the data collection from the interviews, and were recorded in notes in the field diary. The field notes enabled additional and complementary information to be generated to record words, phrases, and points related to the investigated environment, such as location and visual presentation. During the interview meetings, the installations of the productive and administrative units, the work locations of the interviewees, and the meeting rooms were visited. For example, in one of the units there was an outdoor area close to the employees' canteen, with the phrases "what is your big idea today?". In other units, characteristics of the family environment were revealed by the inclusion of photos of the family members in the managers' work environment.

The validity of the research depends on the use of operational techniques to reduce or eliminate errors and increase the possibility of explaining the data. In this case, Yin (2010) suggests triangulation to increase the credibility and reliability of the research. The triangulation occurred via an analysis of the text from the interviews, of the internal records, and of the documents.

The operationalization occurred using the Nvivo 10 software, generating a report, by codified category, with the passages from the interviews and from the material used codified into each one of the categories. In this study, an axial codification was used, which consists of "relating categories to their subcategories and [...] occurs around the axis of a category" (Strauss \& Corbin, 2008, p. 123). The axial codification was used due to the categories already having been established in the research construct.

The data analysis began at the same time as the transcription of the interviews with the reading and review of the documents, of the field notes, and of the transcribed and categorized text in accordance with the categories of analysis. The content of the interviews and alignment with the study categories were systematically reviewed and discussed by the researchers at various points during the interpretation and analysis of the results.

\section{DISCUSSION AND RESULTS OF THE RESEARCH}

\subsection{Contextualization of the Family Group}

The Sport Group represents a large sports items company from Brazil, with more than 40 years of activities and industrial units in operation in Brazil and abroad, which generate approximately 10,000 jobs. It also features investment opportunities, partnerships with sports brands, expansion and internationalization, which are characteristics that have contributed to the continuity and consolidation of the businesses. The management of the family-owned group is undergoing a transition process, with two generations (father and sons) in command in strategic positions. Milestones in the historical trajectory of the Sport Group include expansion and growth in the industrial solutions (private label) segment, and own and licensed brands. The corporate structure of the controlling company is that of a joint-stock company, with characteristics of a holding company exercised in the form of control of the economic group by a board of directors presided over by the owner. 
In 2012, the Sport Group underwent a restructuring process, also carrying out the role of entity of economic control. There was a structural change from decentralization to centralization of the decision-making process, with directorship and sectoral restructuring, repositioning managers and brands and reducing operating costs, thus denoting a more centralizing attitude. The configuration of the family management (owner-controller, working together, and management/ company) has an influence on the structure when it proposes and carried out changes needed in the company. The adaptation of the organization to its environment corroborates the premises of Contingency Theory as part of the adapted functionalism (Donaldson, 2001). It is understood that the involvement and influence of the family in the ownership and management are relevant factors that determine the degree of centralization of the decision-making, with consequences in the use of MCSs to achieve the strategy and, consequently, performance.

\subsection{Analysis and Discussion of the Interface between the Use of the MCSs and the Company Strategy in the Family Business}

Assumption 1 mentions that the beliefs systems and boundary systems enable the implementation of the differentiation and innovation strategy in the family business.

In the characterization of the strategic position, elements of environmental uncertainty, information system, organizational structure, and product differentiation and innovation were identified. The evidence collected in the Sport Group denotes, with greater emphasis, that it operates in an entrepreneurial environment and presupposes constantly and aggressively pursued innovation, via risky investments, creativity, and new challenges, as well as experiencing uncertain, dynamic, heterogeneous, and hostile environments, indicating precepts from the literature (Craig \& Dibrell, 2006; Miller $\&$ Friesen, 1982). Investments were carried out in the last five years in nine industrial plants, performance test laboratories, a biodynamics laboratory, and new product prototypes factory. The new ventures required investments of more than $\mathrm{R} \$ 20$ million in machinery, equipment, and installations, and operate with professionals with expertise in technological training and marketing.

Also observed in the case being studied is a very close interface between innovation and the needs of potential consumers, as shown by Manager 2: "In this business unit [brand] the consumer is indirectly involved [...], the fundamental principle says value for the consumer and for the product, so, it is in this that the company has been investing heavily, in innovation." Product innovation is present in the creation of new models, "product design and appearance and issues linked to health, well-being, and comfort", highlights Manager 3. In the report, it is found that in an indirect relationship with the consumer, the family manager's power of reaction is proactive; that is, he responds to the uncertain environment and promotes an alignment between the strategy and the structure in pursuit of survival and better performance. The study confirms the influence of the environmental contingencies to promote performance, revealed by Miller and Friesen (1982), such as product adaptation in accordance with consumer habits, sharp price competition between own and licensed brands and leading brands in the market, product competition with China and Asian countries, government interference, and labor.

Learning to stimulate corporate entrepreneurialism is supported by employee initiative. The initiative and socialization of the learning occur among groups of employees in the working units. It was found that this practice is stimulated by senior management, brand managers, and product development, forming "an umbrella program of innovation, which stimulates the generation of talents and constant learning in the organization", as Manager 5 reinforces. This type of initiative forms part of the beliefs systems from the LOC perspective and also corroborates the research findings of Bruining et al. (2004) and Widener (2007). The statements of the managers in the Sport Group highlight the influence of the family in promoting the organizational values, in the learning, and in the strategic decisions, which is consistent with the literature (Sharma et al., 1997).

Since 2009, the Operations Day has occurred annually as a way of integrating senior management with the brand and unit managers, and which is an occasion on which "managerial information is evaluated, such as planning, targets, results, and financial and non-financial indicators", notes Manager 5. In addition, sustainability projects, social projects, and new practices instituted in the units are divulged, and financial rewards are given to the unit managers with the best performance and growth. The meeting serves as an opportunity to divulge the good management and operational practices instituted in each unit of the organization in the year in course. This type of action is consistent with learning practices and relates with precepts from the literature (Simons, 1995).

According to Manager 4, "the organization's values were the agenda of the Operations Day meeting held in 2014, and family and non-family managers discussed new values to be instituted" based on the current work philosophy. Similarly, the family values instilled by the family-member managers (owner and sons) reveal the commitment to 
promoting the development and continuity of the family business. The organization's values were shown to be decisive in the beliefs system, which is a characteristic mentioned by Diehl (2006) to reveal the identity of the employees within the organization.

Based on the statements and documents, it is understood that the family values and the management philosophy are the basis for instituting the beliefs system to interact with the strategy of focusing on innovation and increasing competitive advantage. The family unit affirms its commitment via strategies that promote product differentiation and innovation, revealing the shared family and business vision. Continuity is shown by the preparation of the second generation (sons) to assume leadership roles in the companies in alignment with the interests of the family business' strategic plan.

In the case of the Sport Group, this may be accentuated due to the company's values representing family concerns and values. According to the statement of Manager 4, the values instituted in the company are values defended "in house" and are related with the values and principles observed in the business environment. The influence of the family is perceived in the promotion of a culture of innovation, which is considered a competitive differential by the family-member managers. However, Manager 4 highlights the difficulty in carrying out changes to introduce new values in the organization because "changing a culture is extremely difficult".

As was identified in the interviews and in the documents analyzed, innovation in the Sport Group has been motivated since 2009, as a result of the need for changes and adaption to contingency factors identified in the competitive environment: increased competition, brand repositioning, and an improvement in product quality, process efficiency, and operations. It is perceived that the CEO and the family-member managers have a very clear and well-defined vision regarding the need for the employees to adopt new beliefs, new values, and a culture of innovation.

It was found that the vision, mission, and values elements "are formally divulged via the code of conduct and the organization's website", as Manager 1 indicates. The code of conduct states the employees' commitment to the confidentiality of the products. The relationship with partners and customers is guided by standards of product development and standardized by rules defined in specific contracts. It is perceived that the boundary systems define actions that the employees should avoid; yet, they allow the freedom to innovate in certain areas, especially in the elaboration of projects that lead to improvements in productive and administrative processes.
As according to the above, there is evidence in the interviewees' report and in documents of the precepts of assumption 1 . The study provides empirical evidence of belief systems being part of the family strategy to implement a culture of innovation as being a value perceived by the employees. Thus, as the literature advocates, an alignment is noted with the interests of the family-member managers, which include commitment and values for the consolidation of the family business (Acquaah, 2013; Carlock \& Ward, 2001; Chrisman, Chua \& Kellermanns, 2009; Diehl, 2006; Miller et al. 2007; Padilla et al., 2015).

Assumption 2 affirms that the interface between the MCSs and the company strategy is enabled by the joint use of interactive control systems (adaptation to the environment) and diagnostic control systems (implementation of the strategy) in the family business.

In the reports, concern among the interviewees was found with regard to highlighting the achievement of goals, the budget, the indicators, and the meetings to evaluate the performance measures in accordance with the strategic planning, which were emphatically pronounced in the interviews and aligned with the evidence collected from the literature (Simons, 1994). The diagnostic control systems help the managers in monitoring and correcting deviations from pre-established objectives in order to achieve performance, which is consistent with Simons (1995).

It was discovered that, in the Sport Group, the business plan and the budget for each one of the brands consist of the main interface mechanisms between strategy and performance. Regarding the elaboration and the methodology of the budget, based on the report of Manager 4, "it is elaborated and approved in the last four months of the year and monitors the organization's priorities and strategic objectives". The budgetary information should be "closest to the reality, even iffor this it is necessary to approve the budget in the last month of the year", indicates Manager 4. With regard to the technical elaboration process, the discussion of the budgetary plan occurs "via goals, the evaluation of deviations, and strategic priorities", Manager 5 evaluates. It thus follows that the budget primarily aims to guarantee the achievement of the financial targets, as well as influencing the implementation of the strategy.

The budget was the managerial artifact mentioned by all the managers. It was also indicated as the main performance, monitoring, and strategy implementation control, revealing evidence of joint and complementary use in the case being studied. According with the report of Manager 4, "the budget serves as a mechanism of control and evaluation of goals", as well as its "role of coordinating and communicating the strategic priorities, 
linked to a bonus system", aligning the company's interests with the managers' commitment at the various levels of responsibility. The findings of the research indicate that the budget fulfills the assumption of the joint use of diagnostic and interactive controls and reinforces the alignment between the differentiation and innovation strategy and the performance measures. This result supports the study by Bedford et al. (2016) in terms of the complementary use between the MCSs.

The use of interactive controls associated with the differentiation strategy was revealed to be more compelling in the monitoring of the consumers than in the customer relations of the Sport Group, according to Manager 2. The relationship with the customer occurs directly (due to the resale of the product) and indirectly with the consumer (monitoring). The consumer public is approached via social media, in order to divulge the product and attribute value to the brands.

The use of interactive control systems is found in the resolution of problems on the initiative of employees of the Sport Group; it is motivated and instituted via "projects that use the lean manufacturing tool with a focus on developing new products, on product quality, on operational efficiency, and on reducing operating costs", Manager 3 highlights.

It was found that the use of tools, such as market research and digital media, with potential consumers, together with the infrastructure of innovation, promotes the differentiation of its products compared to the competition. In this case, the alignment of new resources and the investment and flexibility in the use of the information motivate learning, as well as the adjustment of strategies to disseminate the importance of innovation within the culture of the organization.

In the case under analysis, the use of diagnostic controls and interactive controls presents evidence that is consistent with assumption 2; however, it is perceived that the diagnostic controls act in monitoring and fulfilling the goals and, consequently, in achieving performance. The composition of the family business, with the ownercontroller in senior management, the sons in strategic roles, and the management in the professionalization stage, with non-family managers, reveals the use of interactive controls adapted to the competitive environment to adjust to the strategies, in accordance with the family interests. The findings reveal consistency with other studies, such as those of Widener (2007), Oyadomari (2008), Mundy (2010), and Acquaah (2013), according to which interactive control systems are associated with organizations that are more receptive towards learning and innovation.

\subsection{Analysis and Discussion of the Interface between the MCSs and the Performance Measures in the Family Business}

Assumption 3 states that the MCSs (diagnostic and interactive) enable the decision-making processes with the use of financial and non-financial performance measures in the family business.

Although all the dimensions studied are important in the context of the Sport Group, it was found that the emphasis of the managers on the use of performance measures is within the economic-financial dimension. The performance measures in relation to the strategic goals are based, primarily, on financial measures, and next on non-financial ones. Widener (2007) explains that organizations should take advantage of all the benefits of performance measures and use them both diagnostically and interactively. This empirical evidence reveals that the managers of the Sport Group are concerned about fulfilling the short-term financial objectives. The economicfinancial indicators that most presented evidence of use were earnings before interest, taxes, depreciation, and amortization (EBITDA), profit margin, and growth in sales or turnover. The findings revealed similarities with the studies by Kowalewski, Talavera, and Stetsyuk (2010).

Regarding the diagnostic use, performance occurs via the use of the budget and forecasted results analysis in formal meetings foreseen in the meetings chronogram (quarterly and annual). This finding is consistent with Simons (1994, p. 171), in that "formal feedback is used to monitor organizational results". It is also inferred that the interactive use occurs in informal and extraordinary meetings between managers and senior administration, to discuss and improve projects, which suggests that the innovation (of products and of processes) occurs based on the use of the management controls also revealed by Oyadomari et al. (2010).

In the analysis of the customer indicators, it was found that the Sport Group saw a reduction of around $8 \%$ in its customer portfolio in the period from 2011 to 2013. This evidence emerges from the fact that the group blocked defaulting customers, concentrated its sales revenues on large chains, and reduced the product mix due to the growth in competition from foreign brands. It is inferred that in the case of the sales to large chains, the strategy is to obtain greater visibility and product valuation (internet sales). It is understood that the non-financial measures and the diagnostic controls are adequate to provide information on performance with periodic information on the customer portfolio and product sales by brand.

The results indicate the use of non-financial indicators in the business environment that involve product innovation. 
The development of key performance indicators aims to indicate internal parameters and evaluate the efficiency of production to reduce costs. The managers of each unit receive reports with cost-minute information on the products to monitor production performance. Yet, the need highlighted by the managers to develop products is that of Key Performance Indicators (KPIs) to measure the innovation projects. The aim is to create performance measures for each project, notes Manager 2, whose "processes should begin in the development of the project and run until sales performance". In this case, the occurrence of a strategic adaptation to adapt the control systems to the use of non-financial performance measures is inferred. Among the main measures used are the number of patents, new products, investment in $\mathrm{R} \& \mathrm{D}$ (percentage of revenue), and investment in new processes (percentage of revenue).

Evidence revealed the use of internal (formal) controls and mechanisms and financial measures to evaluate whether the strategy was being implemented as planned, as well as evaluating the achievement of the strategies in the business environments (brand and private label management). However, an emphasis on the cost monitoring indicators most widely used in the private label segment is perceived. It is understood that, in this case, the parameterization of the product development costs contributes to the achievement of the strategies and the financial objectives.

In light of the market uncertainty, managers of the Sport Group used information on financial measures to stimulate the discussion between the family and nonfamily managers and adjust to the strategic scenario, due to the dynamic environment, thus confirming assumptions of the literature (Simons, 1995, 2000) and empirical evidence (Cruz \& Nordqvist, 2012; Sciascia, Mazzola \& Kellermanns, 2014). The monitoring of financial performance measures is also used to evaluate the growth of the family business in the face of strategic risks. The interactive use of non-financial measures aims to identify and monitor specific problems signaled by the brand and unit managers, as a way of prioritizing solutions in light of the strategic uncertainties of each business plan.

The financial indicators that most presented evidence of use were EBITDA, profit margin, and growth in sales or turnover. The findings revealed similarities with the studies by Anderson and Reeb (2003), Kowalewski et al. (2010), and Frezatti et al. (2014), and support Patel and Chrisman (2014) in explaining that, in this particular case, unsatisfactory performance, monitored by the sales control, promoted changes in senior management to reduce the variability in sales. However, unlike what the authors describe, in this case the investments in innovation were aggressive and, consequently, with associated risks.

As mentioned, there is empirical evidence related to assumption 3 that the diagnostic and interactive control systems facilitate decision-making processes with the use of financial and non-financial performance measures in the family business. However, in this study, financial information was revealed to be more widely used by the management. The findings are consistent with Sciascia et al. (2014), who present arguments that family management is positively related with profitability.

\subsection{Interface between the MCSs and the Strategy and Performance Measures in the Family Business}

Based on the previous topics, the interface between the MCSs and the strategy and performance measures has been partially discussed. In this section, the aim is to highlight elements that characterize the elements as a whole, as established in the general research objective.

Regarding the interface between MCS and strategy, theoretical support was sought in the belief systems and interactive controls. According to the reports, the relevance was perceived of the family values aligned with the organizational values to stimulate the innovation processes. The initiative for resolving problems is incentivized via organizational learning. Thus, new ideas and innovation projects are proposed by the employees to improve the operational processes linked to product quality, efficiency, and reducing operating costs. These projects are discussed and shared between managers and senior administration.

It was observed that the interactive controls are shaped and adapted to the environment as management analyzes budgetary deviations and communicates strategic decisions; periodically, the use of performance measures and goals is discussed between peer managers and senior management; new performance measures are created, for example, in the production area and projects for new products, in order to align strategies with the interests of management.

The family-business duality characterizes the family company in the business environment. The issuing of "customized controls" consists of the adjustment that is interlinked with the MCS and that forms part of the context between the strategy and the performance measures.

The management controls are adapted according to the role of each manager and with the possibility of issuing "customized controls" considered by the managers to be effective in generating daily information and routines 
adapted to the decision-making process. Manager 3 mentions that certain reports are specific to each area, for example:

product management, product sales analysis, materials analysis, other reports are focused more on brands. Others are for controlling the accessories part, materials that have a higher turnover or that have less than 180 days. I use 10 reports, while another manager can have another 10 different reports.

The flexibility and adaptability of the use of the MCSs mainly takes place with regard to the "customized controls" issued by the integrated management system (Business Intelligence-Enterprise Resource Planning - BI-ERP) used by the brand and corporate unit managers.

The strategic planning presents an important role in promoting the continuity and unity of the family management unit, the generation and maintenance of the employees, and finally, to avoid the decline and loss of business for the Sport Group.

In the interface between the MCSs and performance measures, it is perceived that the management of the Sport Group prioritarily evaluates financial measures and the achievement of goals; however, there is a perceived concern of management about seeking new non-financial performance measures primarily to evaluate innovation projects. It is noted that certain performance measures are created and adapted to the needs of the brand and unit managers in order to prioritize and identify solutions in the face of the strategic uncertainties of each business plan. Thus, the results reveal consistency with Simons $(1995,2000)$ and Craig and Moores (2010).

The study revealed that the family has an influence on the relationship between the MCS and the strategy, since the strength of the values is perceived here; this draws attention to an element that is barely discussed in the Simons (1995) model and opens up room for the study's fundamental contribution: the family values present in the management are revealed in the belief systems that shape the use of the MCSs and the strategic behavior of the organization.

With the transgenerational perspective, the presence of the sons in the companies in strategic roles indicates continuity and long-term management. In this case, the level of involvement of the owner and of authority in the organization brings benefits to the family and interacts with the new generation, which is keen to preserve its equity stake.

In the relationship between the MCSs and the performance measures, the family does not allow the distancing of management from efficient and effective processes, given that there is a permanent pusuit of financial results. However, the perpetuity of the family business for the next generations is not left aside in the performance analysis; there was direct reference to the family management when, even with the reduction in profitability, the Sport group did not decide to cut employee costs.

\section{CLOSING REMARKS}

The purpose of this study was to analyze how the interface occurs between the use of MCSs and the strategy and performance measures in a family business, from the perspective of Contingency Theory. The aim was spread out over three research assumptions. The study was developed in a large-sized family business from the footwear and textiles sector.

Based on the statements and documents, the Sport Group carried out significant investments in infrastructure for $\mathrm{R} \& \mathrm{D}$ and innovation, adopting processes and leadership in technology; yet, the economic-financial performance in the analysis period was not as desired by the managers. The organization carried out changes and internal adjustments, for example, restructuring sectors, repositioning own and licensed brands, and reducing operating costs. It is noted that, due to the dynamic environment, the strategy underwent adjustments by means of experimentation, whose influence was derived from the integrated management system and from the family, mainly via the use of the budget and the business plan. In this case, the CEO and owner aligns the family's interests (ownership and continuity) with the business objectives, as well as those of the family and non-family managers in the execution and control of the operational targets and results.

Notably, the two systems (beliefs and boundaries) contribute to promoting the strategy, each one with its own function: the beliefs, mainly via the values (such as those defended "in house") such as respect, competence, and integrity; the boundaries, to guide the internal and external relations with the stakeholders. It is thus understood that the use of belief systems was fundamental for the implementation of the corporate strategy, similarly to the empirical findings of Marginson (2002), to promote change and a culture of innovation, but unlike Widener (2007), in which the "in house" values guide the beliefs and 
direct the strategies. These results present new empirical evidence and suggest new studies regarding the belief and boundary systems from Simons (1995), which have still barely been explored.

It is also inferred that the two systems (diagnostic controls and interactive controls) are complementary in the organization and that the "customized controls", issued by the integrated management system (BI-ERP), take the form of an adjustment of the MCSs to enable the interface between strategy and performance.

The configuration of the family management conceived by the controlling owner, with an entrepreneurial vision and working together (father and sons), influenced the conception of the organizational values and in the culture of innovation and demonstrated particularities of familybusiness dualities that contribute to the implementation of the strategy and, consequently, to performance. It is understood that this study contributes to presenting evidence of family values in the belief systems that has not been shown by the literature.

In this study, the evidence of the family values and of entrepreneurial learning reinforces the use of belief systems and of interactive control systems to adapt to an environment with changes, which are characteristics of entrepreneurial orientation. The family management is especially noted in the belief systems that irradiate fundamental values extracted from the family base, cultural factors, non-financial aspects, and the preservation of the company's wealth, throughout the organization.

It is noted that the study reveals organizational dilemmas in the company. A focus was found on product innovation and the presence of the children in management, which characterize long-term implications.
In contrast, the managers mention the use of financial performance measures and a focus on the budget, generally associated with short-term objectives (Farrel, Kadous \& Towry, 2008; Ittner, Larcker \& Rajan, 1997; Merchant, 1990).

The study also presents limitations. In this case, the perception of the participants in the study regarding the questions that guide this research may not be sufficiently comprehensive, and thus may not have revealed important points for improving the understanding of the facts and situations that developed this topic, as well as the full understanding of the researchers regarding the context of the organization, which is a limiting factor due to them not experiencing the day-to-day of the research subjects. As a single case is concerned, the results cannot be generalized, but they reveal indications of the occurrence of the phenomenon in the context of a family business.

For future research, we suggest the application of the LOC framework from Simons (1995) in longitudinal empirical studies of family businesses, in order to broaden the understanding regarding the influence of family values over organizational values and how these aspects are reflected in the MCS. In the involvement of the family in management, we suggest the use of the family-power, experience, and culture (F-PEC) model (Astrachan, Klein \& Smyrnios, 2002) due to the inclusion of the culture dimension, to evaluate the influence of the family and businesses. We suggest exploring the use of MCSs in family and non-family businesses with the aim of comparing the use of the controls in different management configurations, such as centralization and decentralization, for example. The LOC framework could be explored in different contexts, such as other segments or sectors.

\section{REFERENCES}

Acquaah, M. (2013). Management control systems, business strategy and performance: a comparative analysis of family and non-family businesses in a transition economy in subSaharan Africa. Journal of Family Business Strategy, 4(2), 131-146.

Alves, A. B. (2010). Desenho e uso dos sistemas de controle gerencial e sua contribuição para a formação e implementação da estratégia organizacional (Master's Dissertation). Accounting Sciences, Universidade de São Paulo, São Paulo.

Anderson, R. C., \& Reeb, D. M. (2003). Founding-family ownership and firm performance: evidence from the S\&P 500. The Journal of Finance, 58(3), 1301-1327.

Astrachan, J. H., Klein, S. B., \& Smyrnios, K. X. (2002). The F-PEC scale of family influence: a proposal for solving the family business definition problem. Family Business Review, 15(1), 45-58.

Bedford, D. S., Malmi, T., \& Sandelin, M. (2016). Management control effectiveness and strategy: an empirical analysis of packages and systems. Accounting, Organizations and Society, $51,12-28$.

Beuren, I. M., \& Oro, I. M. (2014). Relação entre estratégia de diferenciação e inovação e sistemas de controle gerencial. Revista de Administração Contemporânea, 18(3), 285-310.

Beuren, I. M., Santana, S. V., \& Theis, M. B. (2014). A interrelação entre os sistemas de controle gerencial e as estratégias organizacionais: um estudo de caso. Revista de Administração, Contabilidade e Economia, 13(3), 919-954. 
Bisbe, J., Batista-Foguet, J.-M., \& Chenhall, R. (2007). Defining management accounting constructs: a methodological note on the risks of conceptual misspecification. Accounting, Organizations and Society, 32(7), 789-820.

Bisbe, J., \& Malagueño, R. (2009). The choice of interactive control systems under different innovation management modes. European Accounting Review, 8(2), 371-405.

Bisbe, J., \& Otley, D. (2004). The effects of the interactive use of management control systems on product innovation. Accounting, Organizations and Society, 29(8), 709-737.

Bruining, H., Bonnet, M., \& Wright, M. (2004). Management control systems and strategy change in buyouts. Management Accounting Research, 15(2), 155-177.

Bruno, F. da S. (2016). A quarta revolução industrial do setor têxtil e de confecção: a visão de futuro para 2030. São Paulo, SP: Estação das Letras e Cores.

Cadez, S., \& Guilding, C. (2008). An exploratory investigation of an integrated contingency model of strategic management accounting. Accounting, Organizations and Society, 33(7), 836-863.

Canan, I., Martins, G. A., \& Oda, P. (2016). Compromissos dos contratos psicológicos e uso diagnóstico dos sistemas de controle gerencial. Revista de Educação e Pesquisa em Contabilidade, 10(2), 181-195.

Carlock, R .S., \& Ward, J. L. (2001). Strategic planning for the family business: Parallel planning to unify the family and business. London: Palgrave Macmillan.

Chenhall, R. H. (2003). Management control systems design within its organizational context: findings from contingencybased research and directions for the future. Accounting, Organizations and Society, 28(2), 127-168.

Chenhall, R. H. (2006). Theorizing contingencies in management control systems research. In: Chapman, C. S., Hopwood, A. G., \& Shields,. M. D. (Orgs.). Handbook of Management Accounting Research (Vol. 1, Chap. 7, pp. 163-206). Amsterdam: Elsevier.

Chrisman, J. J., Chua, J. H., \& Kellermanns, F. (2009). Priorities, resource stocks and performance in family and nonfamily firms. Entrepreneurship Theory and Practice, 33(3), 739-760.

Craig, J., Dibrell, C., \& Garrett, R. (2014). Examining relationships among family influence, family culture, flexible planning systems, innovativeness and firm performance. Journal of Family Business Strategy, 5(3), 229-238.

Craig, J., \& Dibrell, C. (2006). The natural environment, innovation, and firm performance: a comparative study. Family Business Review, 19(4), 275-288.

Craig, J., \& Moores, K. (2010). Strategically aligning family and business systems using the Balanced Scorecard. Journal of Family Business Strategy, 1(2), 78-87.

Cruz, A. P. C., Frezatti, F., \& Bido, D. S. (2015). Estilo de liderança, controle gerencial e inovação: papel das alavancas de controle. Revista de Administração Contemporânea, 19(6), 772-794.

Cruz, C., \& Nordqvist, M. (2012). Entrepreneurial orientation in family firms: a generational perspective. Small Business Economics, 38(1), 33-49.
Davila, A., Foster, G., \& Li, M. (2009). Reasons for management control systems adoption: insights from product development systems choice by early-stage entrepreneurial companies. Accounting, Organizations and Society, 34(3), 322-347.

Diehl, C. A. (2006). Gestão estratégica de custos: identificando o alinhamento estratégico em uma empresa de segurança. Contabilidade Vista \& Revista, 17(1), 69-97.

Donaldson, L. (2001). The contingency theory of organizations. Thousand Oaks, CA: Sage Publications.

Duran, P., Kammerland, N., Essen, M. V., \& Zellweger, T. (2016). Doing more with less: innovation input and output in family firms. Journal Academy of Management, 59(4), 1224-1264.

Farrell, A. M., Kadous, K., \& Towry, K. L. (2008). Contracting on contemporaneous versus forward-looking measures: an experimental investigation. Contemporary Accounting Research, 25(3), 773-802.

Frezatti, F., Bido, D. S., Cruz, A. P. C., \& Machado, M. J. C. (2014). O papel do Balanced Scorecard na gestão da inovação. Revista de Administração de Empresas, 54(4), 381-392.

Gersick, K. E., Davis, J. A., Hampton, M. M., \& Lansberg, I. (1997). Generation to generation: life cycles of the family business. São Paulo, SP: Negócio.

Henri, J. F. (2006). Management control systems and strategy: a resource based perspective. Accounting, Organizations \& Society, 31(6), 529-558.

Hsu, L.-C., \& Chang, H.-C. (2011). The role of behavioral strategic controls in family firm innovation. Industry and Innovation, 18(7), 709-727.

Isidoro, C. (2012). O impacto do desenho e uso dos sistemas de controle gerencial na estratégia organizacional (Master's Dissertation). Accounting Sciences, Universidade Federal do Paraná, Curitiba.

Ittner, C. D., Larcker, D. F., \& Rajan, M. V. (1997). The choice of performance measures in annual bonus contracts. The Accounting Review, 72(2), 231-255.

Junqueira, E. R. (2010). Perfil do sistema de controle gerencial sob a perspectiva da Teoria contingencial (Doctoral Thesis). Accounting Sciences, Universidade de São Paulo, São Paulo.

Kammerland, N., \& Essen, M. V. (2017). Research: family firms are more innovative than other companies. Harvard Business Review. Retrieved from https://hbr.org/2017/01/researchfamily-firms-are-more-innovative-than-other-companies.

Kaplan, R. S., \& Norton, D. P. (1997). A estratégia em ação (6a ed.). Rio de Janeiro, RJ: Campus.

Kowalewski, O., Talavera, O., \& Stetsyuk, I. (2010). Influence of family involvement in management and ownership on firm performance: evidence from Poland., Family Business Review, 23(1), 45-59.

Lavarda, C. E. F., \& Pereira, A. M. (2013). Uso dos sistemas de controles de gestão nas diferentes fases do ciclo de vida organizacional. Revista Alcance, 19(4), 497-518.

Lourenço, C. D. S., \& Ferreira, P. A. (2012). Cultura organizacional e mito fundador: um estudo de caso em uma empresa familiar. Gestão \& Regionalidade, 28(84), 61-84. 
Marginson, D. E. W. (2002). Management control systems and their effects on strategy formation at middle-management levels: evidence from a UK organization. Strategic Management Journal, 23(11), 1019-1031.

Merchant, K. A. (1990). The effects of financial controls on data manipulation and management myopia. Accounting, Organizations and Society, 15(4), 297-313.

Merchant, K. A., \& Van Der Stede, W. A. (2007). Management control systems: performance measurement, evaluation and incentives. London: Pearson Education.

Miller, D., Le Breton-Miller, I., Lester, R. H., \& Canella, A. A., Jr. (2007). Are family firms really superior performers? Journal of Corporate Finance, 13(5), 829-858.

Miller, D., \& Friesen, P. H. (1982). Innovation in conservative and entrepreneurial firms: two models of strategic momentum. Strategic Management Journal, 3 (1), 1-25.

Moores, K., \& Mula, J. (2000). The salience of market, bureaucratic, and clan controls in the management of family firm transitions: some tentative Australian evidence. Family Business Review, 13(2), 91-106.

Mundy, J. (2010). Creating dynamic tensions through a balanced use of management control systems. Accounting, Organizations and Society, 35(5), 499-523.

Nisiyama, E. K., Oyadomari, J. C. T., Yen-Tsang, C., Aguiar, A. B. de. (2016). O uso dos sistemas de controle gerencial e técnicas de gestão operacional. Brazilian Business Review, 13(2), 57-83.

Organization for Economic Co-Operation and Development. (2005). Oslo manual: guidelines for collecting and interpreting innovation data. European Commission: OECD Publishing. Retrieved from http://www.oei.es/historico/ salactsi/oslo4.htm

Oro, I. M. (2015). Interação dos Sistemas de Controle Gerencial com a estratégia e o desempenho organizacional em empresa familiar (Doctoral Thesis). Post Graduate Prgram in Accounting Sciences, Universidade Regional de Blumenau, Blumenau.

Otley, D. T. (1980). The contingency theory of management accounting: achievement and prognosis. Accounting, Organizations and Society, 5(4), 413-428.

Oyadomari, J. C. T. (2008). Uso do sistema de controle gerencial e desempenho: um estudo em empresas brasileiras sob a ótica da VBR (visão baseada em recursos) (Doctoral Thesis). Accounting Sciences, Universidade de São Paulo, São Paulo.

Oyadomari, J. C. T., Cardoso, R. L., Silva, B. O. T., \& Perez, G. (2010). Sistemas de controle gerencial: estudo de caso comparativo em empresas inovadoras no Brasil. Revista Universo Contábil, 6(4), 21-34.
Oyadomari, J. C. T., Frezatti, F., Mendonça, O. R., Neto, Cardoso, R. L., \& Bido, D. S. (2011). Uso do sistema de controle gerencial e desempenho: um estudo em empresas brasileiras sob a perspectiva da resources-based view. Revista Eletrônica de Administração, 17(2), 298-329.

Oyadomari, J. C. T., Pedrique, A. L., Bido, D. S., \& Rezende, A. J. (2014). Uso do controle gerencial e decisões em organizações de saúde brasileiras: um estudo exploratório. Brazilian Business Review, 11(2), 1-34.

Padilla-Meléndez, A., Dieguez-Soto, J., \& Garrido-Moreno, A. (2015). Empirical research on innovation in family business: literature review and proposal of an integrative framework. Revista Brasileira de Gestão de Negócios, 17(56), 1064-1089.

Patel, P. C., \& Chrisman, J. J. (2014). Risk abatement as a strategy for R\&D investments in family firms. Journal Strategic Management, 35(4), 617-627.

Pletsch, C. S., \& Lavarda, C. E. F. (2016). Uso das alavancas de controle de Simons (1995) na gestão de uma cooperativa agroindustrial. Revista de Contabilidade e Organizações, 10(28), 18-31.

Porter, M. E. (1980). Competitive strategy. New York, NY: Free Press.

Sciascia, S., Mazzola, P., \& Kellermanns, F. W. (2014). Family management and profitability in private family-owned firms: introducing generational stage and the socioemotional wealth perspective. Journal of Family Business Strategy, 5(2), 131-137.

Sharma, P., Chrisman, J. J., \& Chua, J. H. (1997). Strategic management of the family business: past research and future challenges. Family Business Review, 10(1), 1-35.

Simons, R. (1994). How new top managers use control systems as levers of strategic renewal. Strategic Management Journal, 15(3), 169-189.

Simons, R. (1995). Levers of control. How managers use innovative control systems to drive strategic renewal. Boston, MA: Harvard Business School Press.

Simons, R. (2000). Performance measurement \& control systems for implementing strategy. Upper Saddle River, NJ: Prentice Hall.

Strauss, A. L., \& Corbin, J. M. (2008). Pesquisa qualitativa: técnicas e procedimentos para o desenvolvimento de teoria fundamentada (2a ed.). Porto Alegre, RS: Artmed/Bookman.

Widener, S. K. (2007). An empirical analysis of the levers of control framework. Accounting, Organizations and Society, 32(7), 757-788.

Yin, R. K. (2010). Estudo de caso: planejamento e métodos (4a ed.). Porto Alegre, RS: Bookman.

Zahra, S. A. (2005). A theory of international new ventures: a decade of research. Journal of International Business Studies, 36(1), 20-28. 